\title{
Exposure to Interbank Investment and Financing Risk by Islamic Banks: A Dynamic Panel Analysis of Malaysia
}

\author{
Mohammad Taqiuddin Mohamad \\ Ahmad Azam Sulaiman \\ Department of Syariah and Economics \\ Academy of Islamic Studies \\ University of Malaya \\ Khairul Hamimah Mohammad Jodi \\ Cluster Education and Sosial Science \\ Open University Malaysia \\ Nazri Muslim \\ Pusat Citra, Universiti Kebangsaan \\ Malaysia
}

\begin{abstract}
The government of Malaysia has developed an Islamic Interbank Money Market (IIMM) since January 1994 with the objective to facilitate funding for the Islamic banking sector in the country. This platform also enables Islamic banks to obtain Shariah-compliant funds from other Islamic banks. This article examines the effects of interbank investment and financing risk on the financing decisions of Malaysia's Islamic bank between 1994-2015. The financing decisions are used as financing measures to determine the effect of investing in the interbank market and financing risk indicators on financing. Research methodology are the descriptive, correlation and dynamic panel analysis results are derived with the help of Limdep 9.0 software. The study found a negative relationship between the interbank investment variable with the financing decisions of Islamic banks. This reflects that an increase in interbank investment leads Islamic banks to reduce their level of financing. These findings prove the investment activities between Islamic banks had a "substitution effect" and decreased their capability of financing because of their tendency to maintain liquidity. Islamic banks are confident that they will generate higher profits in the coming financial year. The economic conditions of Malaysia do not influence Islamic banks' financing decisions, whereas Islamic banks in this study are more dependent on the balance sheet indicators.
\end{abstract}

Keywords: Interbank investment, financing risk, financing decision, Islamic banks.

\subsection{Introduction}

The money market is a segment of the financial market. It is a place where medium and short-term instruments are traded as opposed to the capital market which deals in long-term investments. Here financial assets and securities are highly liquid and have very short maturities. The money market deals with short-term instruments and its function is to bridge economic units temporarily to minimise the gap between their cash receipts and payment such as providing liquidity. Banking institutions can maintain a strategic distance from bank runs by utilising this market as a kind of coinsurance. Moreover, because of the possibility of losing financial assets, theoretically, banks are incentivised to monitor their peers borrowing in this market (Demetrio and Garcia, 2015). The importance of the money market is that it supports the implementation of monetary policy and stable borrowing conditions for the financial sector, other corporations and individuals (Asena, Giulia and Gabriel, 2015). Typically, securities traded in this market consist of negotiable certificates of deposits (CDs), banker's acceptances, treasury bills, commercial papers, municipal notes and others (Zubair, 2013).

The Islamic money market also has a similar function to the conventional money market. Besides serving as a channel for the exchange of financial assets for money, it also provides a short-term capital injection to deficit units where holders of temporary cash surpluses meet holders of temporary cash deficits (Bacha, 2008). Additionally, many investors use the Islamic money market as an interim investment that provides a higher return than holding cash or money in banks. 
Referring to investment opportunities, the Islamic money market provides investment opportunities in various Islamic instruments which are Shariah-compliant. For example, Mudarabah Interbank Investment products (MII) enables Islamic banks with surplus funds to invest in banks facing a deficit using Shariah contracts like Mudarabah, Bay alDayn and Bay al-Inah. The profit-sharing ratio is negotiated between the parties, but the rate of return is based on gross profit before distribution for an investment of one year by the receiving bank. The period of investment is from overnight to 12 months. The minimum amount for the MII is decided by individual banks, and the rate of return is based on the rate of gross profit before distribution for investments of one year by the receiving bank, while the profitsharing ration is negotiable (Florian, Marie and Cornelia, 2015).

In the context of Malaysia, the government has developed an Islamic Interbank Money Market (IIMM) since January 1994 with the objective to facilitate funding for Islamic banks in the country. The initiative by the Malaysian government through Malaysia's central bank has helped the Islamic banking sector achieve outstanding growth performance (Central Bank of Malaysia, 2010-2015). Malaysia's Islamic banking sector also has the ability to access a money market with Shariah-compliant products. This effectively overcomes the major bottleneck to growth and the inability of Islamic banks to manage asset-liability mismatches (Bacha, 2008). After 14 years since its establishment, the Malaysian Islamic money market has experienced rapid growth, in tandem with the vibrant and progressive Islamic financial sector in the country. This is well-reflected by the large amount of funds channelled by the Islamic money market, which ranges from RM30 billion to RM40 billion monthly (Manap, 2008). Reflecting the commitment to turn the country into a global Islamic banking and finance hub, Bank Negara Malaysia (BNM) - continues to remain supportive of the development of the Islamic financial markets. In this regard, BNM continues to provide a conducive policy environment for the Islamic money market to develop, together with the conventional money market (Amin, Faisol and Zulkifli, 2017).

\subsection{Issues and Problems}

Since the beginning of the financial crisis, the interbank market has been carefully scrutinised by commentators and policy-makers. Interbank markets play a crucial role in propagating the distress during the recent financial crisis. It is also considered crucial stress indicators during financial crises as they reveal not only the banks' concerns regarding the risk of financing of their counterparts but also their liquidity needs. Besides that, the monetary policy changes need to be monitored for their long-term effect especially involving financing capability. Unsecured financing creates additional risk between creditors and debtors (Leur, 2016). If a debtor defaults, the lender is subjected to increased risk and has to bear the losses.

The decision to invest in the interbank investment by the management of Islamic banks should take into account the "substitution effect". On the one hand, if there is a rise in interbank investment, it will reflect in the poor liquidity management of Islamic banks because banks also need to fulfil their financing facilities in various sectors. Financing capabilities among Islamic banks should be addressed by enhancing the debtors' solvency (Buigut, 2010). Table 1 aggregately shows the use of the Malaysia Islamic banks funds in various types of financing. During the five years from 2010 to 2015, the direction of financing flow of Malaysia Islamic banks increased from 7\% to 26\% each year with the latest financing in December 2015 reaching RM9192.75 million. 
Table 1: Financing by Type/Sector

\begin{tabular}{|c|c|c|c|c|c|c|c|c|}
\hline \multicolumn{3}{|c|}{ Type of Financing } & 2010 & 2011 & 2012 & 2013 & 2014 & \multirow{3}{*}{$\begin{array}{l}2015 \\
9192.75\end{array}$} \\
\hline & & & \multicolumn{5}{|l|}{ RM Million } & \\
\hline Overdraft & & & 4446.72 & 4780.91 & \begin{tabular}{|l|l|}
5373.58 \\
\end{tabular} & 6280.11 & 7334.10 & \\
\hline \multirow{11}{*}{$\begin{array}{l}\text { Term } \\
\text { financing }\end{array}$} & \multirow{2}{*}{$\begin{array}{l}\text { Hire } \\
\text { purchase }\end{array}$} & Total & 44958.98 & 52468.83 & 57008.71 & 64287.02 & 69976.22 & 72343.30 \\
\hline & & $\begin{array}{l}\text { where: } \\
\text { Passenger } \\
\text { car }\end{array}$ & 41569.31 & 45397.85 & 51313.47 & 57274.69 & 59544.97 & 67539.27 \\
\hline & Leasing & & 875.43 & 1247.72 & 1141.24 & 1252.80 & 1025.59 & 920.37 \\
\hline & $\begin{array}{l}\text { Financing } \\
\text { based on } \\
\text { block }\end{array}$ & & 0.00 & 1.94 & 2.43 & 2.68 & 1.67 & 0.59 \\
\hline & $\begin{array}{l}\text { Connector } \\
\text { financing } \\
\end{array}$ & & 397.59 & 216.84 & 255.08 & 99.40 & 80.85 & 171.52 \\
\hline & $\begin{array}{l}\text { Syndicate } \\
\text { financing }\end{array}$ & & 2061.07 & 2021.32 & 3521.83 & 3340.28 & 4104.77 & 8975.00 \\
\hline & $\begin{array}{l}\text { Personal } \\
\text { financing } \\
\end{array}$ & & 15533.97 & 20289.95 & 25591.70 & 26423.54 & 27525.41 & 27295.80 \\
\hline & $\begin{array}{l}\text { Home } \\
\text { financing } \\
\end{array}$ & & 29824.51 & 37348.95 & 48736.43 & 62839.71 & 78160.11 & 95958.70 \\
\hline & Others & & 43117.28 & 56371.38 & 64662.04 & 82774.33 & 102438.53 & 124325.41 \\
\hline & \multirow[t]{2}{*}{$\begin{array}{l}\text { Due time } \\
\text { which: }\end{array}$} & $\begin{array}{ll}\begin{array}{l}\text { Until } \\
\text { year }\end{array} & 1 \\
\end{array}$ & 3881.06 & 2393.25 & 3233.91 & 2664.52 & 7232.22 & 6198.00 \\
\hline & & $\begin{array}{l}\text { Exceeding } \\
1 \text { year }\end{array}$ & 132887.77 & 167573.69 & 197685.56 & 238355.23 & 276080.94 & 323792.68 \\
\hline $\begin{array}{l}\text { Financing } \\
\text { Bill }\end{array}$ & & & 7878.21 & 8987.62 & 10440.64 & 9606.64 & 9781.29 & 9914.24 \\
\hline $\begin{array}{l}\text { Trustwort } \\
\text { hy receipt }\end{array}$ & & & 664.29 & 647.44 & 655.98 & 609.82 & 535.16 & 711.60 \\
\hline $\begin{array}{l}\text { Revolve } \\
\text { credit }\end{array}$ & & & 6230.40 & 8309.70 & 11557.41 & 16829.15 & 22363.06 & 23727.30 \\
\hline $\begin{array}{l}\text { Financing } \\
\text { in foreign } \\
\text { currencies }\end{array}$ & & & 3956.92 & 4984.23 & 4398.53 & 5947.53 & 9001.44 & 13149.32 \\
\hline Others & & & 2136.27 & 2618.97 & 3278.27 & 3664.19 & 3799.91 & 4165.61 \\
\hline Total & & & 162081.64 & 200295.80 & 236623.89 & 283957.18 & 336128.12 & 390851.49 \\
\hline
\end{tabular}

Source: Central Bank of Malaysia (2010-2015)

In conclusion, based on the above issues and problems, this article seeks to examine the impact of Malaysian Islamic banks' involvement in interbank investment and financing risk on their financing decisions. Bank specifications, monetary policy and economic condition factors are the control variables for this study. The article is divided into seven parts. The first section describes the introduction, issues and problem related to interbank investment, financing risk and financing decisions of Islamic banks in Malaysia. The third section examines the previous research and articles related to this topic. The fourth section details the model and data specification adopted in this research. The fifth section is the finding of the research. Sections sixth and seventh look at the conclusion of the research and suggest the directions of the future research.

\subsection{Literature Review}

This section reviews research that analysed directly and indirectly interbank investment and money markets. The review covers both local and international research. As a general notion, banks with surplus money will invest in the interbank money market while the banks with deficits will borrow in the interbank market. Besides for balancing daily liquidity fluctuations banks participate in the interbank market because they have different marginal costs of obtaining funds from the central bank (Neyer and Wiemers, 2003). The interbank money market enables domestic credit institutions to make available to others (mainly banks) their excess bank balances or where necessary to borrow (or buy) such balances in order to add to their liquidity on the basis of narrow margins (Dali, 2006; Freixas and Jorge, 2008).

Islamic banks having short-term excess liquidity would not adopt such techniques of finance based on trading in cash balances for interest (Leire and Jon, 2017). However, this practice is clearly prohibited by the Shariah rules whereas profit-sharing is acceptable in Islam because it is trading in balances (cash money) with central banks. 
Money from the Shariah point of view is not traded for money. In this situation, the entire money market instrument has to be backed by asset to comply with the Shariah (Ratidya and Salina, 2010). Therefore, the Islamic interbank investment uses the Mudarabah concept and the instrument is named Mudarabah Interbank Investment (MII).

According to Amin, Faisol and Zulkifli. (2017), MII refers to a mechanism whereby an Islamic bank with surplus funds can invest in a bank facing a deficit based on Mudarabah. The profit-sharing ratio is negotiated between the parties, but the rate of return is based on gross profit before distribution for an investment of one year by the receiving bank. Moreover, Saiti and Ali (2016) when discussed the Islamic interbank money market, its instruments and operations, they demonstrate that the existence of a viable Islamic interbank money market is crucial for the successful implementation of an Islamic financial system. They stressed, the availability of various Islamic interbank money market instruments allows Islamic banks to cover their exposure (in case of deficit) and make placement on short-term basis (in case of surplus). Besides, Lahsasna and Shayad (2015) studies about Islamic interbank money market on the Malaysian experience stated it is worth noting that Islamic banks also need to maintain a collection of high-quality liquid assets in order to be able to secure liquidity when facing short-term liquidity shortfalls and to decrease the effects of long-term market volatility.

Nonetheless, Bacha (2008) argues that even though an Islamic money market operates in an interest-free environment and trades Shariah-compliant instruments, many of the risks associated with conventional money markets, including interest rate risks are relevant. Also in practice, secondary trading is very thin due to the small number of players in Islamic money market operations (Ratidya and Salina, 2010).

The conclusion was made after he examined the operation of an Islamic interbank money market (IIMM) within a dual banking system using some of the key risks associated with money market functions. Besides, Kassim and Manap (2008) found that in a dual financial system, the differentials of interest rate between the Islamic and conventional money markets create an arbitrage opportunity for the conventional financial institutions, leaving the Islamic financial institution at a disadvantage since these institutions are limited to transacting only in the Islamic financial market. Even more than that, Ratidya and Salina (2010) said the displaced commercial risk may occur in the situation whereby interest rate on deposit is relatively attractive as compare to the profit rate given to Islamic bank depositor, one would likely see a significant deposit withdrawal from Islamic bank to conventional bank. In this regard, customers of Islamic banks very rational when selecting which Islamic bank offers higher returns and cheaper financing (Sugiyarti, Hilda and Rifki, 2017).

There are a large number of studies of interbank investment in the conventional financial system. For instance, Alexius, Birenstam and Eklund (2014) use a unique data set on traded volume between banks and the bank risk in studying the Swedish interbank market risk premiums. They find that the main determinants of the Swedish interbank premium are international variables, such as the US and EURO area risk premium. International exchange rate volatility and the EURO/USD deviations from CIP also matters while standard measures of domestic market liquidity and domestic credit risk have insignificant effects. Nonlinear smooth transition (STR) models show that the US financial variables are more important in times of a rising US risk premium.

Dinger and Hagen (2009) when they investigate whether banks that borrow from other banks have lower risk levels, confirm that long-term interbank exposures result in lower risk of the borrowing banks. They concentrate on a large sample of Central and Eastern European banks that allows us to explore the impact of interbank lending when exposures are long term and interbank borrowers are small banks.

In the term of liquidity, Craig, Fecht and Tümer-Alkan (2018) found that banks with a more diversified borrowing structure in the interbank market bid significantly less aggressively and pay a lower price for liquidity in the ECB's main refinancing operations. The conclusion derived when they assess how the concentration of credit relationships and the position of a bank in the network topology of the system influence the bank's ability to meet liquidity demand using quarterly data of bilateral interbank credit exposure among all Germany banks from 2000 to 2008 to measure interbank relationships and network characteristics. Eross, Urquhart, and Wolfe (2016) studies liquidity risk contagion within the interbank market by assessing the long-run relationship of short-term interest rate spreads from January 2002 to December 2015. They found that when the short-term interbank market is affected by a liquidity shock, the LIBOROIS spread is a leader in moving back to equilibrium, while the euro-dollar currency swap rate and the US-German bond spreads are followers. Therefore, liquidity shocks propagating within the interbank market can forecast benchmark interest movements, and ultimately this has significant implications for policy-makers and market players alike. 
Allen, Carletti, and Gale (2009) develop a simple model of the interbank market where banks trade a long term, safe asset. When there is a lack of opportunities for banks to hedge idiosyncratic and aggregate liquidity shocks, the interbank market is characterized by excessive price volatility. In such a situation, a central bank can implement the constrained efficient allocation by using open market operations to fix the short-term interest rate.

It can be constrained efficient for banks to hoard liquidity and stop trading with each other if there is sufficient uncertainty about aggregate liquidity demand compared to idiosyncratic liquidity demand. Meanwhile, Freixas, Martin and Skeie (2011) suggested that the central bank should lower the interbank rate when confronted with a crisis that causes a disparity in the liquidity held among banks. Failure to cut interest rates during a crisis erodes financial stability by increasing the risk of bank runs. However, Corrado and Schuler (2017) conclude that stricter liquidity measures which limit inside money creation, dampen the severity of a breakdown in interbank lending. Targeting interbank financing directly through liquidity measures along with a moderate capital requirement generates lower welfare losses.

Moreover, Asena, Giulia and Gabriel (2015) explore the effect of bank lending relationships in the interbank market and show that stable relationships exist and that they played a significant role during the 2007-2008 financial crisis. They use data from the MID market that represents the only transparent electronic platform in Europe and USA, unaffected by search costs and other fictions. Trading with preferred counterparts is associated with more favourable rates for both lenders and borrowers and carries larger trading volumes. The results point to a peer monitoring role of relationship lending, which contributes, at a time of financial distress, to a smooth liquidity redistribution among banks. Relationship lending thus plays an important positive role for financial stability. Besides, Sarmiento and Cely (2017) find that financial institutions with an elevated frequency of signals tend to exhibit a net borrower liquidity position in the interbank market, hence suggesting they are facing recurrent liquidity needs.

Based on the above studies, we found that a specific study related to the interbank market, financing risk and financing decisions of banking institutions has yet to be conducted for Islamic banking.

\subsection{Methodology}

\section{a. Model Specification}

Our study follows the models by Hassan (1993), Hatakeda (2000), Cebenoyan and Strahan (2004), and Sarantis and Nicholas (2009) to examine the role of bank-specific variables, monetary policy and macroeconomic variables in financing growth in Malaysian Islamic banks. Formally, the model used may be presented as follows:

$$
\Delta F D_{i t}=\alpha+\sum_{i=1}^{k} \beta_{k} X_{k i t}+\varepsilon_{i t}
$$

Where;

$$
\begin{aligned}
& \Delta F D_{i t}=\mathrm{FD} \text { ratio, i.e. ratio of FD to gross advance for i-th bank at } \mathrm{t} \text { time. } \\
& \alpha=\text { Constant } \\
& i \text { (index of banks) }=1,2[\ldots] 17 \\
& t \text { (time interval) }=1,2[\ldots] 13 \\
& \beta=\text { coefficients of determinants of FD ratio } \\
& X_{k} \quad=\text { k-th regressor } \\
& K=\text { Number of regressor or independent variable } \\
& \varepsilon_{i t} \quad=\mu_{i}+\lambda_{i}+u_{i t}
\end{aligned}
$$

Where $\boldsymbol{\mu}_{\mathrm{it}}$ is the fixed effect of time, $\boldsymbol{u}_{\boldsymbol{i}}$ is fixed effect firm and $\boldsymbol{\varepsilon}_{i, t}$ is the errors term which are not serially correlate, or it correlates with all variable at time $t-1$. This study defines $F D_{i t}$ as the level of financing offered by Islamic banking that covers every economic sub-sector from the years 1994 to 2015. Due to the lag variable $\left(F D_{i t-1}\right)$ is independent variables in this study, the above specifications of the model developed become inconsistent. Therefore, Arellano and Bover, 1995) and Blundell and Bond (1998) recommended the generalised method of moments (GMM) procedure, which associate the regression in differences with the regression in levels. Using the GMM estimator, the instruments for the level equation are the lagged differences of the corresponding variables, whereas the instruments for the difference equation are the lagged levels. According to Arellano and Bond (1991), the GMM method system is much more consistent and efficient in estimating the coefficients of the model and in solving the problems of endogeneity, heteroskedasticity, and autocorrelation. The dynamic panel technique is also helpful in amending the bias induced by omitted variables in cross-sectional estimates and the inconsistency caused by endogeneity.

\section{b.Empirical Variables}


The dependent variable used in this research is the Islamic banks financing. The explanatory variables are divided into bank-specific determinants, financing risk, monetary policy and macroeconomic determinants. The explanatory variables are selected as suggested in the literature. The descriptions of the variables, the data sources as well as the expected signs are presented in Table 2.

Table 2: Definition of variables

\begin{tabular}{|l|l|}
\hline TERM & Definitions \\
\hline FD & $\begin{array}{l}\text { Financing Decision; This ratio shows the behaviour of banks in the pursuit of profit and } \\
\text { risk-taking. This behaviour is consistent with the profit-sharing paradigm that allows } \\
\text { Islamic banks offer long-term financing to the project risk profile and high returns. }\end{array}$ \\
\hline ROA & $\begin{array}{l}\text { Bank profit; Measurement of profit before tax divided by total assets in the bank. This } \\
\text { variable indicates the number of bank profits to total assets. }\end{array}$ \\
\hline FRISK & $\begin{array}{l}\text { Financing risk; describe the results of risk-taking by banks in the appropriate timeliness. } \\
\text { The dependence of these indicators suggests risk weights based on total assets for } \\
\text { various type of financing and different asset categories. }\end{array}$ \\
\hline CAP & $\begin{array}{l}\text { Capitalisation; Capital and reserves, as a part of the liabilities in the balance sheet total. } \\
\text { This includes paid-up capital, reserve funds, retained earnings and other capital funds. } \\
\text { Capital and reserves comprise own funds or a bank's core capital. More investment risk } \\
\text { was so much more is needed capital. }\end{array}$ \\
\hline SIZE & $\begin{array}{l}\text { Bank size; This ratio represents the ownership of assets by banks. High asset ownership } \\
\text { enables banks to offer more financial services at low cost. }\end{array}$ \\
\hline Money supply; Growth in money supply indicators show real growth potential, \\
especially for future growth.
\end{tabular}

\section{c. Methodology}

To examine the behaviour of Islamic banks financing decisions, this article employs the Generalised Methods of Moments (GMM) estimators. Following the studies on the bank policies in providing loan/financing by Hassan (1993), Hatakeda (2000), Cebenoyan and Strahan (2004) and Sarantis and Nicholas (2009), the use of a dynamic model is important to capture the persistence of financing over time. GMM estimation has gained attention over the years and has provided significant theoretical and applied contributions to the econometrics literature. The GMM estimator also helps to tackle the issue of endogeneity, autocorrelation, heteroscedasticity, unobserved heterogeneity and the persistence of the dependent variables. Specifically, we apply the GMM System estimators of Arellano and Bover (1995) and Blundell and Bond (1998) to cope with potential endogeneity. In order to determine the consistency and validity of the GMM estimator, we perform two diagnostic tests. First, we apply the Sargan test for over-identifying restrictions to test the validity of the instruments. Second, we perform autocorrelations test in the error terms to determine the adequacy of the estimator. 


\section{d. Data}

The sample consists of 17 Islamic banks in Malaysia over the 1994-2015 period. The analysis is based on key Islamic banking market that operates in a dual banking system. The issue of data availability remains a limitation as for the development of Islamic banking in Malaysia. The sample comprised an unbalanced panel of Islamic banks with a minimum of three years and a maximum of 21 years per bank for the 1994-2015 period. The number of Islamic banks is presented in Table 3.

Table 3: Number of Banks by Country

\begin{tabular}{l|lll}
\hline No. & Islamic banks & Ownership & Period \\
\hline 1 & Bank Islam Malaysia Berhad & Local & $1994-2015$ \\
2 & Bank Muamalat Malaysia Berhad & Local & $1994-2015$ \\
3 & Maybank Islamic Berhad & Local & $1994-2015$ \\
4 & RHB Islamic Bank Berhad & Local & $1994-2015$ \\
5 & EONCAP Islamic Bank Berhad & Local & $1994-2015$ \\
6 & Hong Leong Islamic Bank Berhad & Local & $1994-2015$ \\
7 & CIMB Islamic Bank Berhad & Local & $1994-2015$ \\
8 & AmIslamic Bank Berhad & Local & $1994-2015$ \\
9 & Affin Islamic Bank Berhad & Local & $1994-2015$ \\
10 & Alliance Islamic Bank Berhad & Local & $1994-2015$ \\
11 & Public Islamic Bank Berhad & Local & $1994-2015$ \\
12 & Al Rajhi Banking and Investment Corporation & Foreign & $1994-2015$ \\
& (Malaysia) Berhad & & \\
13 & Asian Finance Bank Berhad & Foreign & $1994-2015$ \\
14 & HSBC Amanah Malaysia Berhad & Foreign & $1994-2015$ \\
15 & Kuwait Finance House (Malaysia) Berhad & Foreign & $1994-2015$ \\
16 & OCBC Al-Amin Bank Berhad & Foreign & $1994-2015$ \\
17 & Standard Chartered Saadiq Berhad & Foreign & $1994-2015$ \\
& & & \\
\hline
\end{tabular}

Source: Central Bank of Malaysia (1994-2015)

The bank-level data are collected from the publications of the individual Islamic banks' financial statements that contain comprehensive information on Islamic banks. The financial statements items and ratios are harmonised within a universal format for comparing the sample banks. The interbank investment and monetary policy data are obtained from the website of Islamic Interbank Money Market (Islamic Interbank Money Market, 1994-2015), while macroeconomic data are collected from the Asian Development Bank (Asian Development Bank, 1994-2015).

\subsection{Findings}

\section{a.Descriptive Analysis}

Table 4 presents the estimation results for the baseline specifications for system GMM. Specifically, the table shows the mean, standard deviation, skewness as well as kurtosis and Jarque-Bera for each variable.

Table 4: Descriptive of Variables Statistics

\begin{tabular}{|l|l|l|l|l|l|}
\hline Variable & Mean & Std. Dev. & Skewness & Kurtosis & Jarque-Bera \\
\hline FD $_{\text {t-1 }}$ & 13.50 & 2.95 & -1.97 & 8.80 & $377.44^{*}$ \\
\hline ROA & 0.01 & 0.01 & -0.12 & 11.39 & $511.63^{*}$ \\
\hline FRISK & 0.46 & 0.23 & -0.10 & 2.37 & 3.33 \\
\hline CAP & 41.50 & 364.83 & 9.81 & 101.21 & $76069.98^{*}$ \\
\hline SIZE & 14.54 & 2.11 & -0.37 & 4.58 & $24.76^{*}$ \\
\hline MS & 13.13 & 0.41 & -0.20 & 2.26 & $8.05^{*}$ \\
\hline MII & 4.06 & 1.91 & 1.19 & 2.97 & 64.81 \\
\hline MGS & 3.78 & 1.53 & 0.98 & 2.43 & $47.25^{*}$ \\
\hline GDP & 2.83 & 0.40 & 0.14 & 1.95 & $13.34^{*}$ \\
\hline PI & 2.70 & 1.37 & 0.48 & 2.41 & $14.49^{*}$ \\
\hline
\end{tabular}

Note: ***, ** and * represent coefficients that are statistically significant at the $1 \%, 5 \%$ and $10 \%$ level, respectively. Source: Authors' computations 
To verify whether the sample data is normally distributed, the data will be tested using several techniques such as the skewness test, kurtosis, the Jarque-Bera as well as the value of mean and median. If a sample is normally distributed, then the value of skewness will be equal to zero, the value of kurtosis should be three and the value of mean should be the same as the value of its median while the value of Jarque-Bera should not be significant or with a high value of probability. A sample data that is normally distributed should be an efficient estimator, unbiased and consistent. The results for most variables are fairly stable.

Based on the findings on the descriptive as shown in Table 4, we found that the sample data is not normally distributed. The reason is that none of its characteristics are identical to the one recently discussed. The value of mean and median for all the variables are not the same while their skewness is not equal to zero. The values of kurtosis are not equal to three, and all the values of Jarque-Bera are significant at level 10\%. Therefore, it can be concluded that based on the above, the Ordinary Least Squares estimation method is not a better estimation method to be used. Hence, the Generalised Least Square method is more appropriate and expected to yield a much better result.

\section{b. Analysis of Matrix Correlation}

Before carrying out the regression analysis, the existence of an econometric problem of data set applied in the model is tested by using the correlation matrix. We have checked the independence of variables to ensure the absence of multicollinearity problems that may prejudice our results. The correlations among the variables described in the model can be found in Table 4 . The results confirm that no collinearity problem occurs between the independent variables, as multicollinearity can be considered a problem when the correlation is above 0.80 (Kennedy, 1992). In this regard, the correlation between each of the variables is not elevated, and the highest degree of correlation found is very satisfactory. The matrix shows that multicollinearity problems do not exist, confirming that the model used is valid and reliable. The empirical analysis shows that all the independent variables have a statistically significant relationship with the financing measures included in the model. Overall, we observe that some relevant differences between the findings estimation of the time periods, with respect to both the significance and the size of the coefficients. The regression results on the relationship between Islamic banks financing and the explanatory variables are displayed in Table 5.

Table 5: Matrix Correlation

\begin{tabular}{|c|c|c|c|c|c|c|c|c|c|c|}
\hline & $F D_{t-1}$ & ROA & FRISK & CAP & SIZE & MS & MII & MGS & GDP & PI \\
\hline FD $_{t-1}$ & 1.0000 & & & & & & & & & \\
\hline ROA & -0.1869 & 1.0000 & & & & & & & & \\
\hline FRISK & 0.4898 & -0.0440 & 1.0000 & & & & & & & \\
\hline CAP & -0.5432 & 0.2131 & -0.2320 & 1.0000 & & & & & & \\
\hline SIZE & 0.5481 & -0.1016 & 0.1406 & -0.1168 & 1.0000 & & & & & \\
\hline MS & 0.5399 & -0.1032 & 0.1414 & -0.1070 & 0.9950 & 1.0000 & & & & \\
\hline MII & -0.4071 & 0.1679 & 0.0957 & 0.1016 & -0.5302 & -0.5427 & 1.0000 & & & \\
\hline MGS & -0.0920 & 0.0200 & 0.0912 & 0.0896 & 0.0474 & 0.0010 & 0.5557 & 1.0000 & & \\
\hline GDP & -0.4197 & 0.1655 & 0.0658 & 0.1062 & -0.5536 & -0.5719 & 0.9905 & 0.5689 & 1.0000 & \\
\hline PI & 0.8859 & -0.1468 & 0.2070 & -0.2399 & 0.6500 & 0.6429 & -0.4935 & -0.0921 & -0.5058 & 1 \\
\hline
\end{tabular}

Note: $* * * * *$ and $*$ represent coefficients that are statistically significant at the 1,5 and $10 \%$ level, respectively.

\section{c. Model Estimation}

Table 6 presents the estimation results for the baseline specifications for system GMM. Regression includes bankspecific, monetary policy and macroeconomic variables. The p-values are reported in parentheses in all regressions and $* * *, * *, *$ indicates significance sign at $1 \%, 5 \%$ and $10 \%$ levels respectively. 
Table 6: Estimation Results Using System GMM

\begin{tabular}{|l|l|l|}
\hline \multirow{2}{*}{ Specification } & Estimation Parameter \\
\cline { 2 - 3 } & GMM-Difference & GMM-System \\
\hline FD $\mathrm{t}_{-1}$ & $0.0871^{*}$ & $0.1046^{*}$ \\
& $(2.4755)$ & $(2.2779)$ \\
\hline ROA & -1.1897 & 1.2797 \\
& $(-0.4768)$ & $(0.3381)$ \\
\hline FRISK & $3.0248^{*}$ & $2.2700^{*}$ \\
& $(11.6600)$ & $(2.9838)$ \\
\hline CAP & $-0.0019^{*}$ & $-0.0020^{*}$ \\
& $(-15.9870)$ & $(-15.6427)$ \\
\hline SIZE & $0.7042^{*}$ & $0.7783^{*}$ \\
& $(8.6663)$ & $(8.8067)$ \\
\hline MS & 1.0876 & 0.4277 \\
& $(0.7368)$ & $(0.7483)$ \\
\hline MII & $-0.5965^{*}$ & $-0.3869^{*}$ \\
& $(-4.4083)$ & $(-2.6096)$ \\
\hline MGS & $0.6559^{*}$ & $0.4755^{*}$ \\
& $(3.3014)$ & $(2.3540)$ \\
\hline GDP & -0.5927 & -0.0037 \\
& $(-0.4413)$ & $(-0.0061)$ \\
\hline PI & -0.0065 & -0.0229 \\
& $(-0.2271)$ & $(-1.0957)$ \\
\hline Sargan Test & $126.3045^{*}$ & $3.7883^{*}$ \\
\hline AR(1) & -0.42 & -0.11 \\
\hline AR(2) & -0.89 & -0.77 \\
\hline$*$ Significant at $1 \%$ & $* *$ Significant at 5\% & $* * *$ Significant at $10 \%$ \\
() & & \\
\hline
\end{tabular}

( ) t-value

Sargan Test is referring to exceed limitation recognition

\section{i. Bank Specifics}

The results for most variables are fairly stable across regressions. Specifically, the results passed the diagnostics tests, suggesting that the model is adequately specified. The Sargan test does not reject the over-identification of restrictions in all regressions implying that the instruments are valid. Furthermore, the lagged dependent variable is positive and significant at $1 \%$ level in regressions implying the persistence of the previous financing across time and justifying that dynamic GMM is an appropriate estimator.

Furthermore, the results indicated the higher level of previous financing is influenced by prudent "monetary policy" which leads to an excellent repayment track record of the customers. In addition, the past financing flow provided in many productive sectors is capable of generating high returns to the bank which in turn encourages Islamic banks to offer more financing for the next financial year.

The results suggest that financing risk, capital, and size factors contribute significantly to explaining the financing decisions of Islamic banks. More specifically, the capital structure has a negative effect on financing decision and significant at the $1 \%$ level. A $1 \%$ increase in capital leads to a $0.0020 \%$ decrease in Islamic banks' financing. The findings are consistent with Liu, Beng and Hua, Min (2009) who found Islamic banks improved their provisions in formatting capital and this finding is linked the capital control of the bank (bank capital regulations) either a binding or do not affect the management of bank in offering financing. Regulation for banks that have surplus capital but is bound by the rules occasionally will not increase the offer of financing but also restrict the factors each financing offered resulted in an increase in risk-weighted assets ratio.

On the contrary, financing risk has a positive influence on the financing decisions of Islamic banks and is significant at the $1 \%$ level. An increase in financing risk by $1 \%$ would lead to an increase of $2.2700 \%$ in bank financing. This situation reflects the Islamic banks changed their financing portfolio by moving towards a riskier financing as a reaction to highly decreasing profit from low-risk financing. Islamic banking is involved in various forms of financing such as property, consumer financing, commercial financing, industrial, and others where all of which are involved in the profile and the level of risk, particularly credit risks, as well as other unique risks. Besides that, the effect of their active engagement in the securitisation activity leads the bank to invest in riskier financing for potentially high returns (Hazli and Ismail, 2008). 
In this case, although IBS is a Shariah compliant bank, risk taking activities are not mistaken and not prohibited, and even promoted by Islam on the basis of "al-gunm bi al-ghurm" method that each profit needs to be in line with the risk level taken. However, risk taking activities need to be streamlined with robust and effective risk management tools.

Similarly, the study shows that size has a positive relationship on the financing decisions of Islamic banks by $0.7783 \%$. This shows that the size factor is the primary determinant of whether Islamic banks should increase the financing portfolio or vice versa. These findings are consistent with Sarantis and Nicholas (2009) who found that bank size has the most significant role in differentiating the reactions of banking institutions towards changes in monetary policies by the regulator. Oliver, Yuan and Jeon (2010) also found smaller banks with low liquidity and capitalisation had limited ability to offer financing.

\section{ii. Monetary Policies Changes}

In this section, the study suggests that MII and MGS factors contribute significantly in explaining the financing decisions of Islamic banks. Interestingly, there is a difference between the two variables where MII showed a negative sign while MGS recorded a positive sign. More specifically, in regression, the MII has a negative effect on financing decisions and is significant at the $1 \%$ level. A $1 \%$ increase in MII leads Islamic banks to decrease financing volume by $-0.3869 \%$. The findings are consistent with previous studies by Othman, Ahmad and Kechot, (1992) and proved that the investment activities of Islamic banks (Islamic interbank investment) in Malaysia had a "substitution effect" and decreased their capability to give more financing because of their tendency to maintain liquidity.

On the other hand, MGS has a positive influence on the financing decisions of Islamic banks and is significant at the $1 \%$ level. An increase in MGS by $1 \%$ would lead to an increase of $0.4755 \%$ in Islamic banks' financing. This shows the retention level of high government securities held by Islamic banks will result in high-profit return as well. These returns are distributed in the capital formation by Islamic banks for the purpose of financing (ElGindi, Said and Salevurakis, 2009).

\section{iii. Economic Conditions}

In this section, the results suggest that GDP and PI variables are not statistically significant even though the result is in line with previous theories and studies. Both variables do not affect Islamic banks' financing as shown in regression of Table 5. GDP and PI variables have an insignificant influence on the financing decisions of Islamic banks. This finding is in line with proponents of Islamic bankis in that Islamic mode of financing go toward the real sector and is less inflationary (Tamsir Cam, 2017). In this context, Hazli and Ismail (2008) found that Islamic banks depend more on the balance sheet indicators as a signal for economic condition compared with the general economic performance measurement.

\subsection{Conclusion}

Based on the findings of this study, it appears that the actions of the management of Islamic banks invested their surplus funds into intermediary investment mechanisms affecting their financing decisions during the financial year. Although previous studies have proven bank involvement in interbank investments results in high returns, this study by using different samples found that investment in this form in the context of Islamic banking in Malaysia does not provide high returns. Islamic banks in this study had to face the problem of liquidity constraints. If they invest excessively in interbank investments, Islamic banks are forced to decide to limit their financing. This is because investment in these platforms provides a rapid return to Islamic banks compared to financing activities. However, this decision causes the fund that is invested in the financing sector to decrease. At the same time, this study has proven that risk-taking activities among Islamic banks through financing activities are very positive. This is evidenced by the bank's management actions to increase financing in various sectors when such financing is increasingly risky. Due to the increased risk of financing, Islamic banks are confident that they will generate higher profits in the coming financial year. The economic conditions of Malaysia do not influence Islamic banks' financing decisions, whereas Islamic banks in this study are more dependent on the balance sheet indicators. It is a signal of the economic condition as compared to general measurements for the performance of the economy.

\section{References}

Aburime, U. T. (2009). Impact Of Political Affiliation on Bank Profitability In Nigeria. African Journal of Accounting, Economics, Finance and Banking Research, 4(4), 61-75.

Albertazzi, U., \& Gambacorta, L. (2009). Bank profitability and the business cycle. Journal of Financial Stability, 5, 393-409.

Alexius, A., Birenstam, H. and Eklund, J. (2014). The interbank market risk premium, central bank interventions, and measures of market liquidity. Journal of International Money and Finance, 48, 202. 
Allen, F., Carletti, E., and Gale, D. (2009). Interbank market liquidity and central bank intervention. Journal of Monetary Economics, 56(5), 639-652.

Altunbas, Gambacorta and Marques. (2009). Financial innovation, bank capital and the bank lending channel: A European empiricist's perspective. Conference of Monetary Policy Transmission Mechanism in the euro area its first 10 years. Frankfurt.

Amin, H., Faisol, M., Usim, I. and Sains, U. (2013). The Islamic Money Market. Chapter 5 The Islamic Money Market, Nilai: USIM Publisher.

Arellano, M. and Bond, S;. (1991). Some tests of specification for panel data: Monte Carlo evidence and an application to employment equations. Review of Economic Studies, Vol. 58, pp. 277-297.

Arellano, M. and Bover, O. (1995). Another look at the instrumental variable estimation of error-components models. Journal of Econometrics, Vol. 68 No. 1, pp. 29-51.

Asena T., Giulia L. and Gabriel Montes., Rojas. (2015). The role of bank relationships in the interbank market. Journal of Economic Dynamics and Control, Vol. 59, pp.118-141.

Asian Development Bank. (1983-2016). Asian Development Bank (1983-2016). Asian Development Bank .

Asli, D.-K., \& Huizinga, H. (1999). Determinants of commercial bank interest margins and profitability: some international evidence. The World Bank Economic Review, 13(2), 379--408.

Bacha, O. I. (2008). The Islamic inter bank money and a dual banking system: The Malaysian Experiences. International Journal of Islamic and Middle Eastern Finance and Management., Vol. 23 No. 1, pp. 210-226.

Bashir, A.-H. M. (1999). Risk and Profitability Measures in Islamic Banks: The Case of Sudanese Banks. Journal of Islamic Economic Studies, 1-24.

Ben Naceur, S. (2003). The Determinants of the Tunisian Banking Industry Profitability: Panel Evidence. Applied Financial Economics(11), 317-319.

Blundell, R. and Bond, S. (1998). Initial conditions and moment restrictions in dynamic panel data models. Journal of Econometrics, Vol. 87, pp.115-143.

Bobáková. (2003). Raising the profitability of commercial banks. Biatec, 21-25.

Bourke, P. (1989). Concentration and other determinants of bank profitability in Europe, North America and Australia. Journal of Banking \& Finance, 65-79.

Breusch, T.S. \& Pagan, A.R. (1980). The Lagrange multiplier test and its applications to model specification in econometric. Review of Economic Studies, 47(1), 239-253.

Brooks . (2008). Introductory Econometrics for Finance. New York, United Stated: Cambridge University Press.

Buigut, S. (2010). Is There a Bank Lending Channel of Monetary Policy in Kenya?. International Research Journal of Finance and Economics, Vol. 45, pp.183-192.

Calza, A., Gartner, C., \& Sousa, J. (2003). Modelling the demand for loans to the private sector in the euro area", , Vol. 35, No. 1, h. Applied Economics, 107-117.

Cebenoyan, A.S. and Strahan, P.E;. (2004). Risk management, capital structure and lending at banks. Journal of Banking and Finance, Vol. 28, pp.19-43.

Central Bank of Malaysia (1994-2015). Islamic Interbank Money Market. Kuala Lumpur: Bank Negara Malaysia.

Central Bank of Malaysia (2010-2015). BNM Annual Report. Kuala Lumpur: Bank Negara Malaysia.

Chirwa, E.W. \& Mlachila, M. (2004). Financial reforms and interest rate spreads in the commercial banking system in Malawi. IMF Staff Papers 51, pp. 96-22., 96-22.

Corrado, L., and Schuler, T. (2017). Interbank market failure and macro-prudential policies. Journal of Financial Stability, 33, 133-149.

Craig, B. R., Fecht, F., and Tümer-Alkan, G. (2015). The role of interbank relationships and liquidity needs. Journal of Banking and Finance, 53, pp. 99-111.

Dali, N. R. S. B. M. (2006). Instruments in Islamic money market in Malaysia. Cambridge: The Business Review.

Dinger, V., and Von Hagen, J. (2009). Does interbank borrowing reduce bank risk? Journal of Money, Credit and Banking, 41(2-3), 491-506.

Edgar Demetrio. And Tovar-García . (2015). Exposure to interbank market and risk-taking by Mexican banks. Cuadernos de Economía. Vol. 39 No. 111, pp.157-174.

ElGindi, T., Said, M., and Salevurakis, J. W. (2009). Islamic Alternatives to purely Capitalist Modes of Finance: A study of Malaysian Banks from 1999 to 2006. Review of Radical Political Economics, 4(4): 516-538.

Eross, A., Urquhart, A., and Wolfe, S. (2016). Liquidity risk contagion in the interbank market. Journal of International Financial Markets, Institutions and Money, 45, 142-155.

Fathin, F. Said., \& Ghafar, A. I. (2007). How Does The Change in Monetary Policy Affect Lending Behaviour of Islamic Banking in Malaysia. Journal of Economic Development,, 12(3), 163-77. 
Fekri A, S. (2015). Efficiency assesment of banking sector in Yemen using data development window analysis: A comparative analysis of Islamic nad conventional banks. Benchmarking: An International Journal, 22(6), $1115-1140$.

Florian, H. Marie, H. and Cornelia, H. (2015). Liquidity hoarding and interbank market rates: The role of counterparty risk. Journal of Financial Economics, Vol.118, pp. 336-354

Freixas, X., Martin, A., and Skeie, D. (2011). Bank liquidity, interbank markets, and monetary policy. Review of Financial Studies, 24(8), 2656-2692.

GMID. (1994-2015). Global Market Information Database (GMID). http://www.portal.euromonitor.com.

Golin, J. A. (2001). The Bank Credit Analysist HAndbook: A Guide for Analysts, Bankers and Investor. John Wiley \& Sons.

H. Boyd, J., \& E. Runkle, D. (1993). Size and performance of banking firms: testing the predictions of theory. Journal of Monetary Economy, 31, 47-67.

Hameed M. B \& Kabir, H. (2003). Determinants Of Profitability In Islamic Banks: Some Evidence From The Middle East. Islamic Economic Studies, 11(1), 1-27.

Hassan, M. (1993). Capital market tests of risk exposure of loan sales activities of large US commercial banks. Quarterly Journal of Business and Economic, Vol.32 No.1, pp.27-49.

Hassoune. A., (2008). Islamic banks' profitability in an interest rate cycle. International journal of Islamic financial services, 4, 1-13.

Hatakeda, T. (2000). Bank lending behaviour under a liquidity constraint. Japan and the World Economy, Vol.12, pp.127-141.

Hausman J.A. (1978). Specification tests in econometrics. Econometrica, 46(6), 1251-1271.

Hazli, R., and Ismail, A. G. (2008). Does Islamic banks'securitization involvement restrain their financing activity. Humanomics, Vol.24 No.2, pp.95-109.

Islamic Interbank Money Market. (1994-2015). Islamic Interbank Money Market. Central Bank of Malaysia. Kuala Lumpur: Central Bank of Malaysia. Retrieved from http://iimm.bnm.gov.my/

Kader, and Leong. (2009). The impact of Interest rate changes on Islamic Bank Financing. International Journal of Business Research Papers, Vol.5 No.3, pp.189-201.

Kassim, S. H., and Abdul Manap, T. A. (2008). The information content of the Islamic interbank money market rate in Malaysia. Journal of Islamic and Middle Eastern Finance and Management, Vol.1 No.4, pp. 304-312.

Kennedy. (1992). A Guide to Econometrics. Oxford: Blackwell.

Kennedy. (2008). A Guide to Econometrics (6th ed.). Mass, United Kingdom: Blackwell Pub, Malden.

Kosmidou, K. (2008). The determinants of banks' profit in Greece during the period of EU financial integration. Managerial Finance, 34(3), 146-159.

Lahsasna, A., and Shayad, F. (2015). Islamic interbank money market products: the Malaysian experience of developing new financing instruments. ISRA Research paper; No.73/2014.

Leira, S, J and Jon, C. (2017). Are Islamic banks different? The application of the Radical Affinity Index. International Journal of Islamic and Middle Eastern Finance and Management. Vol. 12, No. 1, pp. 2-29.

Leur, M. W. (2016). Interbank loans, collateral and modern monetary policy. Working Paper Series, ECB - Lamfalussy Fellowship Programme (pp. 1-51). ECB Working Paper 1959, European Central Bank.

Liu, Beng; Hua, Min. (2009). Islamic banking: Interest-free or interest-based? Pacific-Basin Finance Journal, Vol.17, pp. 124-144.

Malaysia, N. B. (2006-2010). Financial Report. Kuala Lumpur: National Bank of Malaysia.

Mathuva, D. (2011). Capital Adequacy, Cost Income Ratio and the Performance of Commercial Banks: The Kenyan Scenario. The International of Applied Economics and Finance, 3(2), 35-47.

Miller, S. and Noulas, A. (1996). The technical efficiency of large bank production. Journal of banking and finance, 20(3), 495-509.

Misman, F. N. (2011, September 26-27). Financing structures, bank specific variables and credit risk: Malaysian Islamic bank. 1-12. Bangkok, Thailand.

Mohammad Taqiuddin; , Joni Tamkin Borhan; Ahmad Azam. (2008). Pengaruh Persekitaran Makroekonomi Terhadap Keberuntungan Bank-Bank Islam Penuh (full-fledged) di Malaysia. Kuala Lumpur, Malaysia.

Molyneux, P., \& Thornton, J. (1992). Determinants of European Bank Profitability: A Note. Journal of Banking and Finance, 16(6), 1173-1178.

Nazri Muslim, Nik Yusri Musa dan Ahmad Hidayat Buang. (2011). Hubungan Etnik Di Malaysia Dari Perspektif Islam. Kajian Malaysia. 29 (1): 1-28.

Nerlove. (2002). Essays in Panel Data Econometrics. Cambridge University Press: Cambridge University Press. 
Neyer, U., and Wiemers, J. (2003). "Why do we have an interbank money market?," IWH Discussion Papers 182, Halle Institute for Economic Research (IWH).

Noulas, S. M., M. Miller, S., \& Athanasios , G. (1997). Portfolio Mix And Large Bank Profitability In The USA. Applied Economics, 29(4), 505-512.

Oliver, María Pía; Yuan Li; Jeon, Bang Nam;. (2010). Competition in banking and the lending channel: Evidence from bank-level data in Asia and Latin America. Journal of Banking and Finance, Vol. 35, pp. 560-571.

Othman, Z., Ahmad, J., and Kechot, M. (1992). Ekonomi Kewangan. Kuala Lumpur, Malaysia: Dewan Bahasa dan Pustaka.

Pasiouras, F., \& Kosmidou, K. (2007). Factors influencing the profitability of domestic and foreign commercial banks in the European Union. Research in International Business and Finance, 21, 222-237.

Process in Malaysia. International Journal of Islamic and Middle Eastern Finance and Management, Vol. 3, No. 1, pp. 7-19

R. Fraser, D., E. Gup, B., \& W. Kalor, J. (2001). Commercial Banking: The Management of Risk. United Kingdom: South-Western College Publishing.

Rahman, A. A. (2009). Lending Structure and Market Risk Exposures: The Malaysian Case. Asian Academy of Management Journal, Vol.14, No.1, pp.1-20.

Rajesh, K. S., \& Chaudhary, S. (2009). Profitability Determinants of Banks in India. International Journal of Global Business, 2(1), 163-180.

Ramlall. (2009). Bank-specific, industry-specific and macroeconomic determinants of profitability in Taiwanese banking system: under panel data estimation. International Research Journal of Finance and Economics, 34, 1450-2887.

Ratidya, S and Salina, H. K. (2010). Roles of the Islamic banks in the Monetary Transmission

Saiti, B., Hasan, A., and Ali, E. (2016). Islamic Interbank Money Market: Contracts, Instruments and Their Pricing. Islamic Capital Markets, pp. 67-100.

Samad, A. \& Kabir.,H. (2000). The Performance of Malaysian Islamic bank During 1984-1997: An exploratory study. International Journal of Islamic Financial Services, 1-14.

Sarantis, and Nicholas. (2009). The bank lending channel and monetary transmission in Central and Eastern European countries. Journal of Comparative Economics, Vol. 37, pp. 321-334.

SESRTCIC. (1994-2015). Statistical, Economic and Social Research \& Training Centre for Islamic Countries, www.sesrtcic.org, 16hb Januari 2011. Statistical, Economic and Social Research \& Training Centre for Islamic Countries,

Short, B. K. (1979). The relation between commercial bank profit rates and banking concentration in Canada, Western Europe, and Japan. Journal of Banking \& Finance, 209-219.

Sudin, H. (1996). Competition And Other External Determinants of The Profitability Of Islamic Banks. Islamic Economic Studies, 4(1), 49-64.

Sufian, F., \& Habibullah, M. S. (2010). Does economic freedom fosters banks' performance? Panel evidence from Malaysia. Journal of Contemporary Accounting $\backslash \&$ Economics, 6, 77-91.

Sugiyarti, F. L, Hilda, Rossieta and Rifki, I (2017). Management Accounting-Strateg Coalignment in Islamic Banking. International Journal of Islamic and Middle Eastern Finance and Management, Vol. 11, No. 4, pp. 667-694.

Tamsir, C. (2017). Determinants of Islamic Banking Growth: An Empirical Analysis. International Journal of Islamic and Middle Eastern Finance and Management, Vol. 11, No. 1, pp. 18-39.

Taqiuddin, M.; Joni, T. B., and Azam, S. (2008). Pengaruh Persekitaran Makroekonomi Terhadap Keberuntungan Bank-Bank Islam Penuh (full-fledged) di Malaysia. Seminar Antarabangsa Penyelidikan Pengajian Pengajian Islam Peringkat Antarabangsa (pp. 1-16). Kuala Lumpur: Academy of Islamic Studies.

Thakor, A. V. (1987). Discussion. The Journal of Finance, 42(3), 661-663.

Tigran, P. and Heiko, H. (2009). Oil Prices and Bank Profitability: Evidence from Major Oil-Exporting Countries in the Middle East and North Africa. IMF Working Paper, 1-21.

Uhomoibhi, A. T. (2009). Impact of corruption on bank profitability in Nigeria. Prosiding Symposium for Young Researchers (FIKUSZ '09), (pp. 7-16).

Wan Zulkifli Wan Hassan, Ezad Azraai Jamsari, Azizi Umar, Zulkifli Mohamad, Jamsari Alias, Nazri Muslim and Md Yazid Ahmad. (2017). The Management of Zakat Distribution In The Practice of Fatwa in Terengganu, Malaysia, International Journal of Civil Engineering and Technology. 8(11): 834-851

Wan Zulkifli Wan Hassan, Ezad Azraai Jamsari, Nazri Muslim, Jamsari Alias, Zulkifli Mohamad and Md Yazid Ahmad. (2018). The Dynamics of Zakat Distribution According to Shafi'i School of Law (Madhhab) in Fatwas of Terengganu State, International Journal of Civil Engineering and Technology. 9(1): 771-783. 
Wan Zulkifli Wan Hassan, Nabilah Abdullah, Nazri Muslim, Jamsari Alias, Azizi Umar, Rozmel Abdul Latiff, Nani Rahayu Sallihuddin, Zulkifli Mohamad, Aminuddin Basir and Nasaruddin Yunus. (2019). Linguistics Elements of Arabic Language Applied by Imam Shafi'i in Islamic Jurisprudence, International Journal of Civil Engineering and Technology.10(1): 1704-1711

Yungucu, B., and Saiti, B. (2016). The effects of monetary policy on the Islamic financial services industry. Qualitative Research in Financial Markets, Vol.8 No.3, 218-228.

Zubair, H. (2013). Islamic banking and Finance: An integrative Approach. Shah Alam: Oxford Fajar Sdb Bhd. 